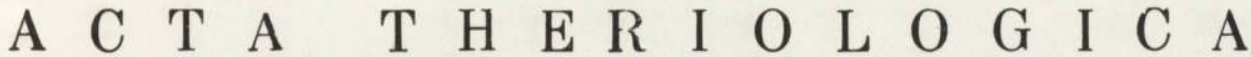 VOL. XVI, 10: 149-159.

\section{An Evaluation of the Qctagon Census Method for Estimating Small Mammal Populations*}

\author{
[With 2 Tables \& 4 Figs.]
}

\begin{abstract}
The aim of this study was to evaluate the results obtained from the octagon census method. Trapping was conducted on the census lines for 28 days. On day 28 a $540 \mathrm{~m}$ assessment line was laid out across the octagon for the purpose of determining the width of the area sampled by the octagon census lines. Traps on assessment lines were set for 4 days. Octagons were set up in four different areas of the mesic-hardwood forest and first trapped during the summer and then retrapped during the winter. Theoretically, captures along the assessment lines shoud show a decline as the census line is approached. This was not the case; more animals were captured at assessment line stations near the census lines than at those assessment line stations farther away. The sudden appearance of animals in an area supposedly voided of inhabitants is difficult to explain. However, because of this phenomenon, the octagon census method failed in its objective of giving density estimates.
\end{abstract}

\section{INTRODUCTION}

Interest in cooperating in the International Biological Program (IBP) has prompted studies designed to standardize small mammal census methods. Good density estimates are needed in studies of bioenergetics and mineral cycling at the population level. Exact data on metabolism and mineral composition can be obtained in the laboratory but when extrapolated to field conditions on the basis of unreliable density estimates, erroneous conclusions result.

Grodziński, Pucek \& R'yszkowski (1968) and other Polish workers (R y s z k ows k i \& Petrusew ic z, 1967) proposed that their "Standard Minimum " method (SM) be adopted internationally. The SM method was tested in the southeastern United States (G e n t r y, G o lle y $\& \mathrm{~S} \mathrm{mith}$ 1968). The results of this preliminary investigation indicated

* This study was carried out under contract AT(38-1)-310 between the University of Georgia and the United States Atomic Energy Commission. 
that, due to varying probability of capture between certain animals and/or species, reliable density estimates could not be determined. Thus, the next logical step was to find a way to estimate the area from which animals are removed by a grid or census line.

Such a method is outlined by Wheeler \& Calhoun (1967) in their proposed International Census of Small Mammals (ICSM). The ICSM is composed of a series of trapping procedures designed to assess the dynamics of small mammal communities in a variety of habitats. Several of the procedures make use of assessment lines to indicate the extent of the sampling area around a grid or census line. This report presents data collected to evaluate the ICSM's octagon census method, category 04 (Wheeler \& Calhoun, 1968).

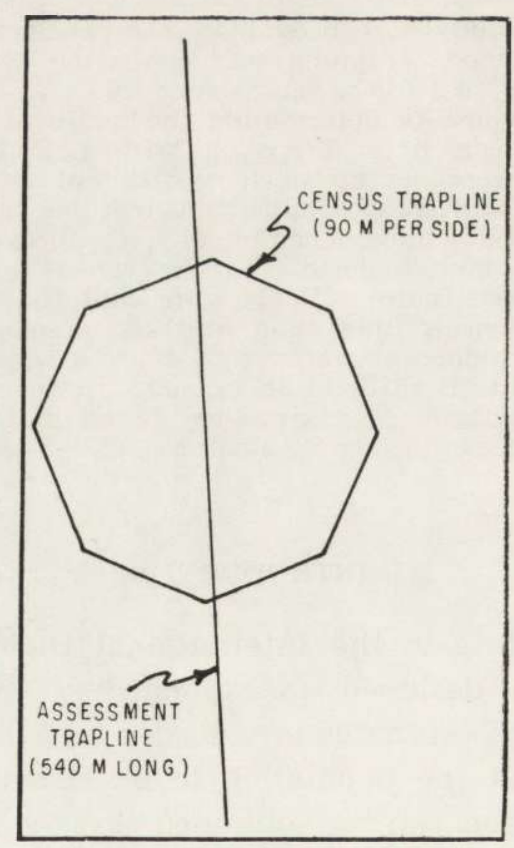

Fig. 1. Diagram of the octagon census trapline with assessment line.

\section{METHODS}

The octagon census trapline with assessment line is illustrated in Fig. 1. The $540 \mathrm{~m}$ assessment line is used to determine the area sampled by the census line, thus allowing an estimate of the density of the small mammals in the area. The census line, arranged in the shape of an octagon, was $720 \mathrm{~m}$ long ( $90 \mathrm{~m}$ per side). Trap stations were spaced $15 \mathrm{~m}$ apart along the census line and $7.5 \mathrm{~m}$ apart on the assessment line. Three small Victor mouse traps were baited with peanut butter 
and set at each station of the octagon census line. The traps were checked, rebaited and reset as necessary each day for 28 days. Location of capture, weight, sex, reproductive condition and species of each animal was recorded. Then, on day 29 , two Victor mouse traps were set at each station on the assessment line and checked daily for four days.

The four study areas were located in the lowland mesic-hardwood forest habitat in South Carolina (see Gentry et al., 1968 for a detailed description). One octagon census line with assessment line was placed in each study area. Trapping was first conducted between July and October, 1968 and again between December, 1968 and March, 1969. Thus, each of the four octagon census lines were trapped twice and are referred to in the data analyses as eight octagons.

Table 1

Number of the three major small mammal species removed by the octagon census trap lines; $(1)=$ summer captures and $(2)=$ winter captures.

\begin{tabular}{|c|c|c|c|c|}
\hline $\begin{array}{l}\text { Trapping } \\
\text { Location }\end{array}$ & Peromyscus & Blarina & Ochrotomys & $\begin{array}{c}\text { Total } \\
\text { Number } \\
\text { Captured }\end{array}$ \\
\hline $\begin{array}{l}\text { Boggy Gut I (1) } \\
\text { Boggy Gut I (2) }\end{array}$ & $\begin{array}{r}14 \\
4\end{array}$ & $\begin{array}{r}13 \\
4\end{array}$ & $\begin{array}{r}11 \\
2\end{array}$ & $\begin{array}{l}38 \\
10\end{array}$ \\
\hline $\begin{array}{l}\text { Boggy Gut II (1) } \\
\text { Boggy Gut II (2) }\end{array}$ & $\begin{array}{l}15 \\
14\end{array}$ & $\begin{array}{l}24 \\
12\end{array}$ & $\begin{array}{l}49 \\
21\end{array}$ & $\begin{array}{l}88 \\
47\end{array}$ \\
\hline $\begin{array}{l}\text { Road F (1) } \\
\text { Road F (2) }\end{array}$ & $\begin{array}{l}29 \\
11\end{array}$ & $\begin{array}{r}23 \\
6\end{array}$ & $\begin{array}{r}10 \\
5\end{array}$ & $\begin{array}{l}62 \\
22\end{array}$ \\
\hline $\begin{array}{l}\text { Cato Road (1) } \\
\text { Cato Road (2) }\end{array}$ & $\begin{array}{l}63 \\
11\end{array}$ & $\begin{array}{r}22 \\
4\end{array}$ & $\begin{array}{r}21 \\
8\end{array}$ & $\begin{array}{r}105 \\
23\end{array}$ \\
\hline $\begin{array}{l}\text { Summer } \\
\text { Subtotal (1) }\end{array}$ & 121 & 82 & 91 & 294 \\
\hline $\begin{array}{l}\text { Winter } \\
\text { Subtotal (2) }\end{array}$ & 40 & 26 & 36 & 102 \\
\hline
\end{tabular}

\section{RESULTS}

Traps on the eight octagons removed a total of 161 cotton mice Peromyscus gossypinus (Le C o n t e, 1853), 127 golden mice Ochrotomys nuttalli (H a rla n, 1823), and 108 short-tailed shrews Blarina brevicauda (S a y, 1823) (see Table 1). Occasional captures of the rice rat Oryzomys palustris ( $\mathrm{H}$ a r la n, 1837), cotton rat Sigmodon hispidus $\mathrm{S}$ a y \& O r d, 1825, southeastern shrew Sorex longirostris B a c h m a n, 1837, eastern woodrat Neotoma floridana (O r d, 1818), eastern harvest mouse Reithrodontomys humulis ( $\mathrm{A} \mathrm{udubon} \mathrm{\&} \mathrm{Bachman}, 1841$ ), and the pine mouse Microtus pinetorum (Le C on te, 1830) totaled 39 and made up $9.8 \%$ of the total number of animals removed. Traps on the 8 assessment 
lines removed 31 P. gossypinus, 37 O. nuttalli, 29 B. brevicauda, 7 O. palustris and $2 \mathrm{~S}$. longirostris.

\section{Seasonal Effects}

There appeared to be a general decline of about $65 \%$ in the numbers of animals trapped during the winter compared to the summer catch (Table 1). Lower trap success was also noted in similar habitat at the same time (K a u f man, S mith, Jones, Gentry \& S mith, 1971). Despite the reduction in animal numbers, there was no appreciable change in species composition when viewed in this way with season.

Table 2

The time at which $50 \%$ of the total number of each species was removed by snap trapping on octagon census lines for 28 days. Data from one octagon were not included due to a very low number of captures. Means given plus or minus one standard error. (1) = summer; $(2)=$ winter.

\begin{tabular}{|l|c|c|c|c|}
\hline \multicolumn{1}{|c|}{$\begin{array}{c}\text { Trapping } \\
\text { Location }\end{array}$} & Peromyscus & Blarina & Ochrotomys & Mean \\
\hline & & & & \\
Boggy Gut I (1) & 7 & 14 & 10 & $10.3 \pm 2.0$ \\
Boggy Gut II (1) & 5 & 12 & 14 & $10.3 \pm 2.7$ \\
Road F (1) & 2 & 6 & 8 & $5.3 \pm 1.8$ \\
Cato Road (1) & 9 & 13 & 11 & $11.0 \pm 1.1$ \\
Boggy Gut II (2) & 5 & 23 & 7 & $11.7 \pm 5.7$ \\
Road F (2) & 12 & 13 & 15 & $13.3 \pm 0.9$ \\
Cato Road (2) & 7 & 5 & 18 & $10.0 \pm 4.0$ \\
\hline \multicolumn{1}{|c|}{ Mean } & $6.7 \pm 1.2$ & $12.3 \pm 2.2$ & $11.9 \pm 1.5$ & $10.3 \pm 1.1$ \\
\hline
\end{tabular}

\section{Rate of Removal of Rodents}

Removal rates varied between species and study areas. Although $P$. gossypinus was not always removed in the greatest numbers, their removal rate was the highest of the three most abundant species (Table 2). Data from the second (winter) trapping of Boggy Gut I was not used in these calculations due to the extremely low number of animals caught (see Table 1). The mean time needed to remove $50 \%$ of the $P$. gossypinus was significantly less than the time needed to remove the same proportion of the $O$. nuttalli or $B$. brevicauda $(P<.05)$. Overall there was no difference in removal rates between $O$. nuttalli and $B$. brevicauda $(P>.05$; Table 2$)$.

To better understand daily changes in removal rates, a corner station of the octagon was taken as zero distance, the next station in a clockwise direction as $15 \mathrm{~m}$ and continuing thus to the sixth station $75 \mathrm{~m}$ from the corner station and on the same side of the octagon. Data from each 
side of the octagon was considered separately and then the data from all sides were combined. Captures were accumulated across distance and the data were used to calculate the linear regression formula $\mathrm{Y}=a+b \mathrm{X}$ for each day. The relationship between the daily values of $a$ and $b$ were calculated for each of the three abundant species (Fig. 2A) and for the three species combined (Fig. 2B). The slope of the relationship is directly related to the rate at which animals were caught. Significant differences between the slopes for different species indicate
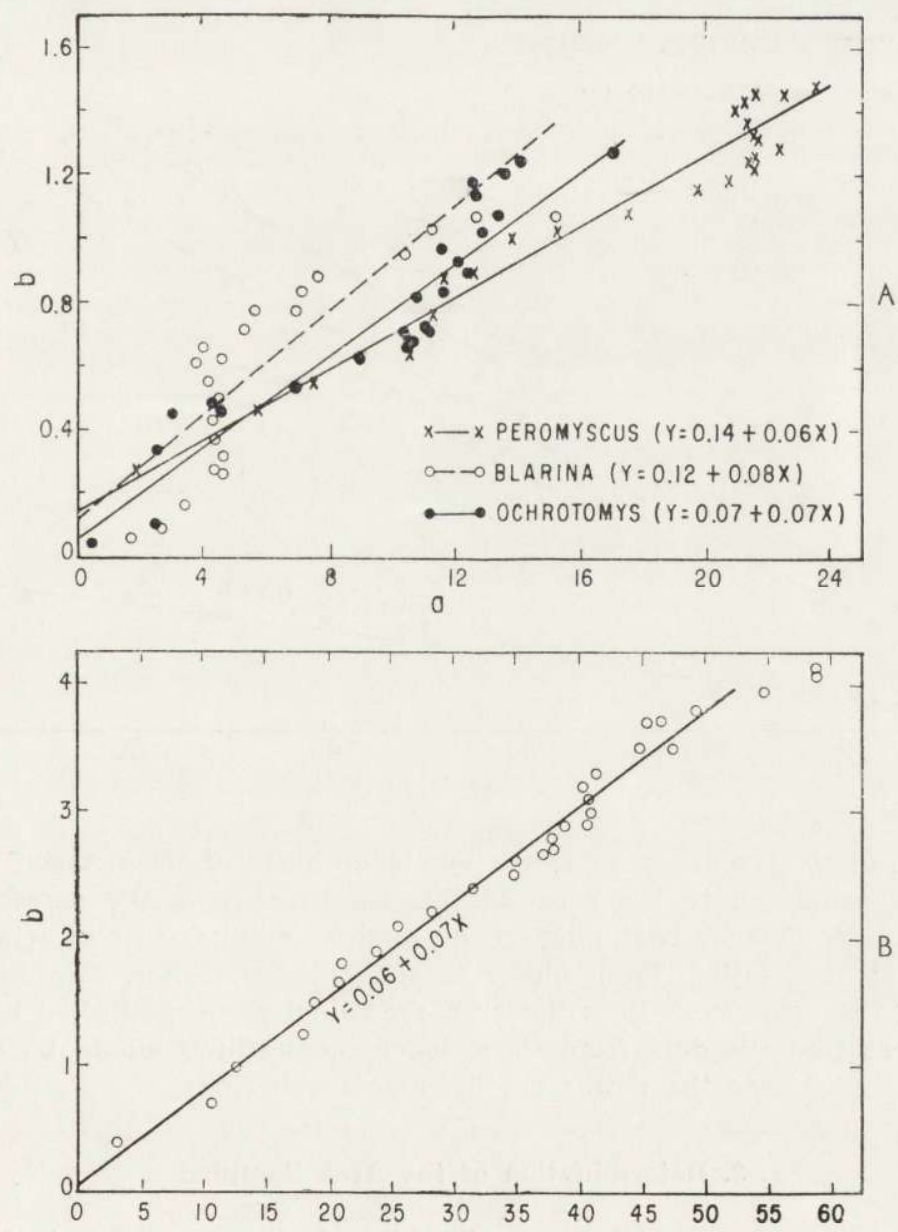

Fig. 2. Slope (b) versus $\mathrm{Y}$-intercept $(a)$ of the linear function $\mathrm{Y}=a+b X \quad(\mathrm{X}=$ distance along census lines; $Y=$ accumulative captures) calculated from the data for each day on all of the trapping areas combined. The slope of the relationship is directly related to the rate at which small mammals were captured over the entire trapping priod. $(A)$ by species; $(B)$ three species most abundant in numbers combined. 
different capture rates as calculated over the entire trapping period. A species, such as $P$. gossypinus that is removed quickly from an area would have a higher intercept and lower slope than an equally abundant species (e.g., $O$. nuttalli) that is removed at a slower rate. The slope for $P$. gossypinus was less than that for B. brevicauda or $O$. nuttalli $(P<.01)$. There was no difference between the slope for $B$. brevicauda and $O$. nuttalli $(P>.05)$.

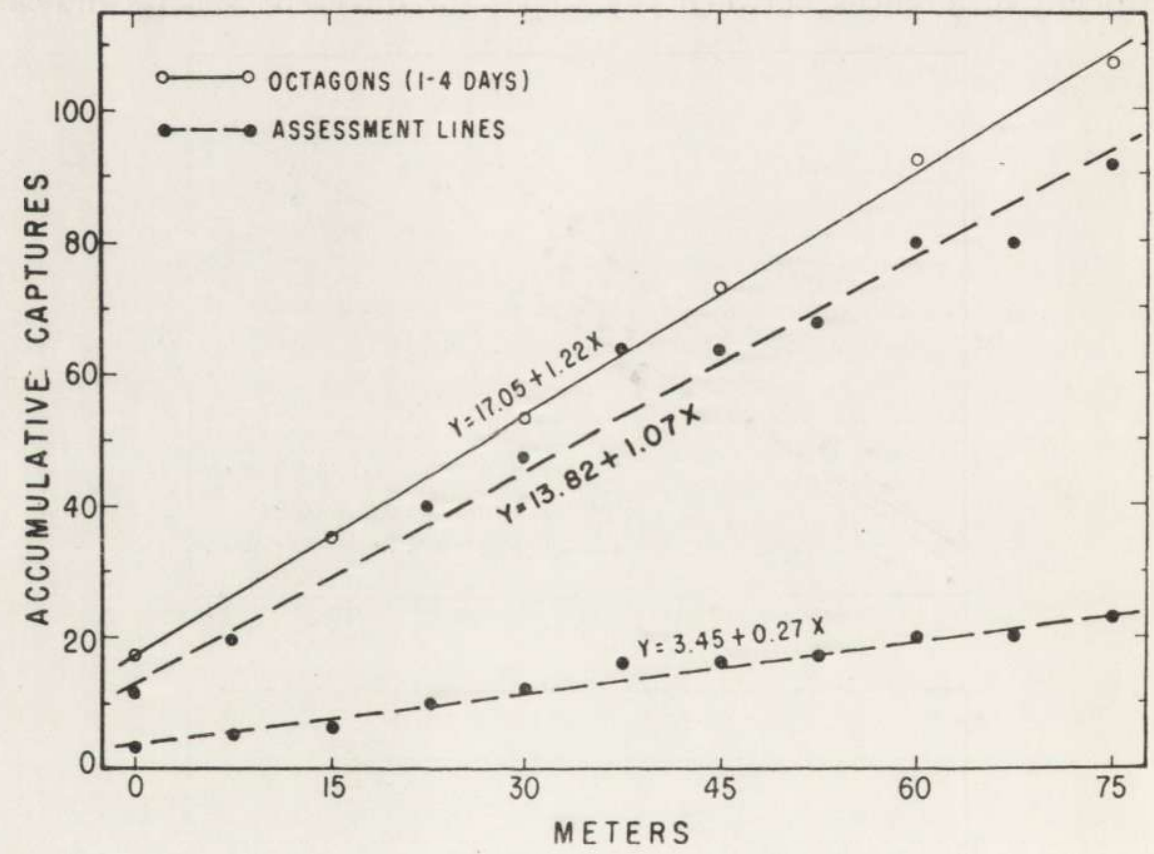

Fig. 3. Accumulative captures along the combined sides of the octagon at the end of four days compared to the accumulative captures along the assessment lines for a comparable distance beginning at the farthest point from the octagon center and ending at the station $75 \mathrm{~m}$ closer to the octagon center. Captures at each station along the assessment lines (lower dashed line) were multiplied by four (top dashed line) so that the data from the octagon census lines would be comparable to the data from the assessment lines.

\section{Determination of the Area Sampled}

Accumulative captures along each side of the octagon at the end of four days were compared to the accumulative captures along the assessment line for a comparable distance beginning at the farthest station from the octagon center and ending at the station $75 \mathrm{~m}$ closer to the octagon center (Fig. 3). Only five octagons could be used for this comparison due to the low number of captures on the census lines of 
two octagons combined with no captures on their assessment lines. Another octagon could not be used because of a local flood which caused a delay in trapping and biased the results from the assessment line. Since the regression for the octagon census lines was based on data from 40 individual lines (5 octagons and 8 sides per octagon) and the regression for the assessment lines was based only on 10 lines of comparable length, the resulting regression lines were not directly comparable. To alleviate this problem, the captures at each station along the assessment lines

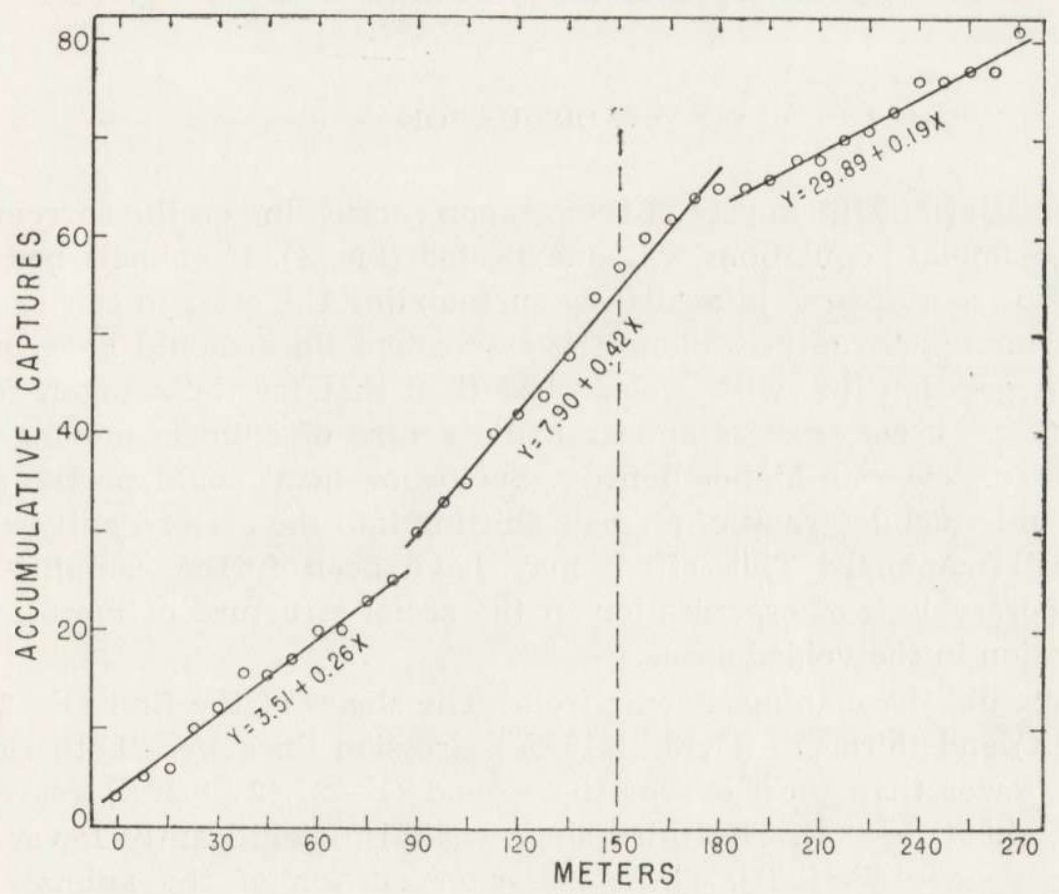

Fig. 4. Accumulative captures along the assessment lines beginning at the station farthest from the octagon center extending into the center (2 lines and 5 octagons $=10$ lines). The vertical dashed line represents the census line. Associated $r$ values were significant at the .01 level.

were multiplied by a factor of four and the resulting regression was calculated. There was no significant difference between the slopes of the regression for the octagon census lines and those of the corrected assessment lines $(P>.05$; Fig. 3).

Theoretically, data from the assessment lines can be used to calculate the amount of area sampled by the octagon census lines, and thus allow an estimate of density to be made. The width of the sampling area of the octagon is indicated by a reduction in the number of small mammals 
captured along the assessment line for a given distance on both sides of the octagon census lines. An area of effect about the census lines was noted in the present study (Fig. 4). However, instead of a reduction in the small mammal population about the census line, there was a significant increase in the acumulative captures over distance $(P<.001)$ beginning at about $120 \mathrm{~m}$ from the ends of the assessment lines, continuing across the octagon census lines and ending at about $180 \mathrm{~m}$. The increased number of captures occurred over a distance of approximately $34 \mathrm{~m}$ outside the octagon and approximately $26 \mathrm{~m}$ inside the octagon for a total of $60 \mathrm{~m}$.

\section{DISCUSSION}

The pattern of the impact of the octagon census line on the surrounding small mammal populations was unexpected (Fig. 4). If animals had been removed from an area immediately surrounding the octagon census lines, the accumulated captures along the assessment lines should have produced a regression line with a slope less than that for the octagon census lines (Fig. 3). Our results appear to be a case of animals moving from an area of lower to higher density. Such movement could be the result of a highly mobile group of animals shifting into the area recently voided of small mammals. This effect may have been further amplified by a temporary lack of organization in the social structure of more mobile population in the voided space.

Where did these animals come from? The slopes of the first $(Y=2.23+$ $+0.19 X)$ and third $(Y=17.13+0.15 X)$ regression lines were both significantly lower than the slope of the second $(Y=21.42+0.39 X)$ regression line $(P<.001 ;$ Fig. 4). The third slope was also significantly lower than the first slope $(P<.01)$. Thus, a greater portion of the animals may have come from inside the octagon. This is true if the assessment lines were long enough to extend into an area unaffected by the census lines. In order to make accurate density calculations, we must assume that animals did not move in from a distance greater than $150 \mathrm{~m}$ from the census line. However, if the ambient rate of capture on the ends of the assessment lines had remained the same throughout the lenth of the lines, then the accumulative captures up to the center of the octagon $(270 \mathrm{~m})$ should have been 53.53 animals. The actual value at $270 \mathrm{~m}$ was 58 animals. The extra animals caught on the assessment lines around the census lines and inside the octagons plus those caught on the census lines could not have come from the inside of the octagon.

One alternate hypothesis is that the assessment lines were not long enough to detect all of the movements. According to more recent studies, 
such an assumption may be valid. For example, Faust, Smith \& Wray (1971) found that by increasing the grid size from a $16 \times 16$ (5.8 ha) to a $26 \times 26(15.2 \mathrm{ha})$, the average distance between captures was increased $19.4 \%$ for $O$. nuttalli and $25.1 \%$ for P. gossypinus. Their live-trap study was carried out at the Savannah River Plant in the same type of habitat as our study. A damczyk \& Ryszkowski (1968) found that both Clethrionomys glareolus ( $\mathrm{S} \mathrm{ch} \mathrm{r} \mathrm{e} \mathrm{be} \mathrm{r,} \mathrm{1780)} \mathrm{and} \mathrm{Apode-}$ mus flavicollis (M elchior, 1834) moved an average of 157 and $180 \mathrm{~m}$, respectively, within a period of three days. T a n to n (1969) reported maximum distances moved within 24 hours by $C$. glareolus and A. sylvaticus (L in n a e s, 1758) as 196 and $285 \mathrm{~m}$, respectively. In our study, it is likely that the census lines were sampling animals from areas not being evaluated by the assessment lines. Since there was no indication of the actual area from which small mammals were removed, reliable density estimates could not be calculated.

The fact that the octagons with assessment lines did not result in reliable denstiy estimates does not necessarily mean that the octagon census method will not work. In a similar habitat, $\mathrm{Ka}$ ufman et al (1971) found that with a larger octagon with several assessment lines, reliable density estimates could be calculated. It may be, in our study, that more replication was needed to reduce variation due to density, habitat, weather, season and other environmental factors. If this were true, another problem is suggested. One octagon requires considerable time and labor to complete and is not likely to result in a reliable density estimate with densities we encounter in South Carolina. In addition, a relatively large amount of uniform habitat is necessary for a series of octagons. Therefore, an investigator with limited time, funds and habitat would probably not consider using this method. On the other hand, the basic idea of an assessment line to determine the area from which small mammals have been removed may be a good one and should be more fully investigated.

Acknowledgements: We wish to thank Frank B. Golley and Donald W. $\mathrm{Kaufman}$ for their criticisms and suggestions concerning preparation of the manuscript. One of the authors, Mr. Chelton, was killed in an automobile accident before the manuscript was completed.

\section{REFERENCES}

1. A d a mczyk K. \& Ryszkowski L., 1968: Estimation of the density of a rodent population using stained bait. Acta theriol., 13: 295-311.

2. F a u st B. F., Smith M. H., \& Wray W. B., 1971: Distances moved by small mammals as an apparent function of grid size. Acta theriol., 16: 161-177. 
3. Gentry J. B., Golle y F. B. \& Smith M. H., 1968: An evaluation of the proposed International Biological Program census method for estimating small mammal populations. Acta theriol., 13: 313-327.

4. Grodziński W., Pucek Z. \& Ryszkowski L., 1966: Estimation of rodent numbers by means of prebaiting and intensive removal. Acta theriol., 11: 297314.

5. Ka $\mathrm{u}$ man D. W., Smith G. C., J ones R. M., Gentry J. B. \& S mith M. H., 1971: Use of assessment lines to estimate density of small mammals. Acta theriol., 16: 127-147.

6. Ryszkowski L. \& Petrusewicz K., 1967: Estimation of energy flow through small rodent populations. [In »Secondary Productivity of Terrestrial Ecosystems«, Ed. Petrusewicz K.]. Państw. Wyd. Nauk., 1: 125-146. Warszawa-Kraków.

7. Wheeler G. G. \& Calhoun J. B., 1967: Programs and procedure of the International Census of Small Mammals (ICSM). U. S. Dept. Health, Education and Welfare, National Institute Mental Health, Bethesda, Maryland, mimeo., $29 \mathrm{p}$.

8. Wh e e ler G. G. \& Calhoun J. B., 1968: Manual for conducting ICSM census category 04 (octagon census and assessment traplines). ICSM Manual No. 4. Parts 1 and 2, Edition 1, $50 \mathrm{p}$.

Accepted, March 15, 1971.

Savannah River Ecology Laboratory, SROO, P. O. Box A,

Aiken, South Carolina, USA 29801.

or

Athens, Georgia, USA 30601. University of Georgia, Institute of Ecology, Department of Zoology and

John B. GENTRY, Michael H. SMITH i John G. CHELTON

\section{OCENA METODY INWENTARYZACJI OSMIOBOCZNEJ DO SZACOWANIA POPULACJI DROBNYCH SSAKÓW}

\section{Streszczenie}

Zadaniem badań była ocena metody ośmioboku dla inwentaryzacji ssaków (Wheeler i Calhoun, 1968). W metodzie tej odłów ssaków prowadzi się na ośmiu $90 \mathrm{~m}$ rzędach pułapek, połączonych w kształcie ośmioboku (Ryc. 1). Linia taksacyjna o długości $540 \mathrm{~m}$ przecinająca wpoprzek ośmiobok pozwala na oszacowanie zagęszczenia.

Badania prowadzono $\mathrm{w}$ środowisku nizinnego, mezotroficznego lasu liściastego w Savannah River Plant w południowo-wschodniej części USA. Badania na czterech ośmiobokach prowadzono latem i ponownie, następnej zimy. Odłowy na liniach inwentaryzacyjnych prowadzono w ciągu 28 dni, po których następowały 4-dniowe odłowy na liniach taksacyjnych.

W 8 seriach połowów na ośmiobokach uzyskano w sumie 161 osobników Pero myscus gossypinus, (Le Conte, 1853), 127 osobników Ochrotomys nuttalli (H a r la n, 1823) i 108 osobników Blarina brevicauda (S a y, 1823). Te trzy gatunki sta 
nowiły $90 \%$ wszystkich zlowionych zwierząt. Na liniach taksacyjnych odłowiono 31 osobników P. gossypinus, 37 osobników O. nuttalli i 29 osobników B. brevicauda W sezonie zimowym wyłowiono mniej zwierząt (Tabela 1), lecz nie zanotowano znaczniejszej zmiany w składzie gatunkowym.

Mimo, że $P$. gossypinus nie zawsze lowi się w największej liczbie, to wskaźnik wyłowu dla tego gatunku był najwyższy (Ryc. 2A). Sredni czas potrzebny do usunięcia $50 \%$ osobników $P$. gossypinus wynosił $5,6 \pm 1,2$ dnia (Tabela 2). Czas ten byl w sposób istotny krótszy od czasu potrzebnego do usunięcia tej samej proporcji osobników O. nuttalli $(10,0 \pm 1,2$ dni) lub $B$. brevicauda $(13,6 \pm 2,7$ dni; $P<0,05)$.

W badaniach naszych obserwowano obszar wpływu wokół linii inwentaryzacji. Zamiast, jednak, zmniejszenia populacji drobnych ssaków wokół linii inwentaryzacji, następował istotny wzrost $\mathrm{w}$ skumulowanych odłowach $\mathrm{w}$ stosunku do odległości $(P<0,001$; Ryc. 4). Wzrost ten następował $\mathrm{w}$ odległości $34 \mathrm{~m}$ na zewnątrz i $26 \mathrm{~m}$ do wewnątrz ośmioboku; szerokość obszaru wpływu wynosiła zatem $60 \mathrm{~m}$.

Czynniki wywolujące wzrost liczby złowień drobnych ssaków wokół linii inwentaryzacyjnej, zamiast przewidywanego spadku nie były oczywiste. Fakt, że ośmioboki z liniami taksacyjnymi nie dały wiarygodnych oszacowań zagęszczenia w niniejszych badaniach, nie oznacza, że metoda ta nie dziala. W podobnym środowisku $\mathrm{K}$ a u f man et al., (1971) stwierdzili, że przy większym ośmioboku z kilkoma liniami taksacyjnymi, można było wyliczyć wiarygodne oszacowania zagęszczenia. Zasadnicza koncepcja linii taksacyjnej do określania obszaru, z którego usunięt) drobne ssaki może być wartościowa i powinna być pełniej zbadana. 